business. The object is to give every man full scope to do his work to the best of his ability and with the minimum of detailed instructions. An intelligent man works better if he is given personal responsibility for his section of the work. Some instructions, some control and a good deal of co-ordination there must be, but this need not be inconsistent with the freedom of the individual to get on with his own job largely on his own responsibility. Personal relationships between different people in a large organization are of outstanding importance, and tho object is not only to get the highest productivity in the direct or physical sense but also to get workers of all kinds, and particularly the higher grade workers, including scientists, to do their work with a sense of purpose and enthusiasm. No organization is in this respect perfect, and the task of getting many people to work happily and harmoniously is never finished. Indeed, this task of organizing and co-ordinating the work in the many sections of a large organization requires men of the highest intelligence and character.

So much of the work has a scientific foundation that it is desirable that many of the higher posts, probably the majority, should be filled by men with a scientific background. It is quite wrong to assume that the place of the scientist in industry is only in the laboratory, or that the scientist need not bother much about matters outside his particular scientific field. All the operations of a company which is making products of importance to world trade have to be closely co-ordinated, and there is neod for an understanding of the relationships between the marketing of products, their manufacture and the research and development work that goes on all the time to improve the products, to reduce their cost and to find new products. In Imperial Chemical Industries we employ some thousands of men and women with scientific degrees. A proportion of these work in the laboratories; but many of them are engaged on other operations, controlling large sections of work which may be on the production side or on the marketing side, or their tasks may straddle all the operations, from manufacture to sale, of a group of products.

A good scientist who can comprehend not only the problems in a laboratory but also the problems involved in dotermining the scale of production, the erection of a new plant which may cost millions of pounds, or in the control of men either at home or overseas, is the kind of man or woman which is needed in the higher posts in industry. The careors open to scientists are varied and interesting, particularly for those who reach a high academic standard in their particular field of science and also have the capacity to understand the relationship of this work to all the other work in a large industrial organization. The chemical industry has been uppermost in my mind, but much of what I have been saying is equally relevant to other industries, such as aircraft manufacture, the metal industries, radio, television, transport, and so on: the requirements of high academic standards plus the right character are similar throughout modern industry.

I. have said that the specialist scientist is a botter man if he has also a good understanding of the relationship of his work to the world of science as a whole, but even this is not enough. An understanding of the way in which the country's economy works and, if exports are involved, of social and economic conditions throughout the World is invaluable. I am not suggesting that every chemist, physicist or engineer must also be an economist; but I do know that those chemists, physicists or engineers who have a broad background knowledge of economic principles can do their work with a better understanding of its significance and are likely to be better candidates for higher executive posts where they have to control and co-ordinate work over a wide field than the specialists who lack any such background. The future for seientists in industry is bright; the best prospects are for those good scientists who have just something more than their scientific qualifications.

There is another goneral point which is inescapable. With the growing productivity of human effort as scientific methods are applied throughout industry and commerce, we shall be able to produce the material things of life with ever-shortoning working hours, even if this shortening is a gradual process, extending over many years. The shortening of hours, whether we are considering either the shortening of the number of hours worked per day, or the number of days worked per weok, or the number of weeks worked per year, will mean, I believe, an increase in leisure time, and with rising standards of living an increase in the money that can be spent in leisure time. This itself will raise certain problems. In particular, how will these loisure hours be utilized? This is a matter which has to be answered by each individual for himself; but I am convinced that higher educational standards can make for a greater enjoyment of life as a whole and not only that part of life which is concerned with work. In cultural matters, in the appreciation of art, music, literature, the better and broader the education, the greater is the capacity for appreciation and enjoyment of all the things that can be done in leisure hours. As our material standards of living rise, the need to preserve a balance in education between science and the humanities and arts becomes more apparent.

\title{
OBITUARY
}

\section{Dr. M. J. Cross}

Mrchael Cross died in an air crash in Tennessee on July 9 on his way to a scientific meeting.

Cross possessed a rare combination of fine qualities of character and intellect, and his death at the age of thirty-seven is a ser!nus loss for medical research. He received his early oducation at Cranley School, where he won an open exhibition and the St. Nicholas Scholarship. During 1944-47 he was in the Royal Naval Volunteer Reserve which he left as sub-lieutenant. In 1947 he went up to New College, Oxford, with an open exhibition and read for an honours degree in chemistry. After graduating in 1951, Cross took up research in Oxford as Guinness Research Fellow in microbiology, working under Prof. D. D. Woods, and in 1954 he obtained the D.Phil. dogree for a thesis on the metabolism of serine by microorganisms. At first his work was concerned with tho inter- relationship of carbon dioxide and citrovorum factor in the requirement for serine by Leuconostoc; he showed that carbon dioxide prevented the breakdown of citrovorum factor. Later he worked on the synthosis of methionine by Escherichia coli, and he was largely responsible for the dovelopment of a cell-free system which has been the basis for many subsequent advances. The results of this work were published between 1951 and 1960 in a series of papers in the Journal of General Microbiology and in the Biochemical Journal.

Although Cross was then well on the way towards a fine career in biochemistry he took the unusual step of becoming a student again to study medicine in the Oxford Medical School. During that time he kept himself up to date in his earlier subject by tutoring his fellow medical students at New College in organic chemistry. After graduating in December 1959 Cross was successively house physician to Prof. L. J. Witts at the Radeliffe 
Infirmary and house surgeon to Mr. Frank Ellis at the Churchill Hospital. Cross's work in clinical medicine was highly thought of and he was happy doing it. Howover, it became clear to him that his deepest interests lay, after all, in research. His successive training in chemistry and medicine was idcal for starting him in medical research with every hope that he would be able to make important and useful contributions to knowledge. From what he had already achieved when ho died, this hope was fully justified.

Cross often said that he would like any research on which he was engaged to have a good ehance of being clinically useful. He was therefore happy when he was asked to join an investigation into biochemical aspects of blood coagulation and thrombosis. For this he came to the Department of Pharmacology at the Royal College of Surgeons of England in London. The College made him Research Fellow, and he was supported by the Medical Research Council. Soon he had his first success by discovering a way of stabilizing thromboplastic activity in plasma and of separating the activity by high-speed centrifugation. The active material appeared to react directly with prothrombin, and Cross showed that the kinetics of the reaction were as might be expected if 'plasma thromboplastin' were an enzyme. For the first time, therefore, it became proper to describe 'plasma thromboplastin' as a substance with the properties of an enzyme and, hence, as plasma prothrombinase. Cross showed further that when centrifuged in the absence of calcium plasma prothrombinase splits into two fractions. One fraction is heat-labile and contains protein : the other resists heating and contains phospholipid. In this way Cross confirmed experimentally the well-known suggestion made by Macfarlane many years ago that 'plasma thromboplastin' consists of two components, one a protein and the other a lipid; and Cross showed that the components are bound together by calcium.

Cross then became involved in a study of the factors that control the adhesiveness of blood platelets. Interest in this had just been stimulated by the discoveries that platelet adhesiveness is greatly and specifically increased by adenosine diphosphate and that this increase is prevented by other, closely related, substances. Cross made important contributions to the clarification of these effects, including the demonstration that they require a plasma protein which is present in the fibrinogen fraction. It now seems that deficiency in this protein causes von Willebrand's disease. Most of Cross's work in this field has been published in Nature, in Thrombosis et Diathesis Haemorrhagica, and in the Journal of Physiology.

From September 1963 until his death Cross and his family had been living in the United States. He went there with a Fullbright Travel Scholarship as Buswell Research Fellow in Biochemistry of New York State University. With Dr. Douglas Surgenor, first in Buffalo and then in Woods Hole, he continued working on the identification of the plasma protein already referred to and on other important subjects. He was invited to contribute to several conferences, including the annual symposium on "Blood" at the Mayo Clinic. Britain could have had no finer representative in the United States than Michael Cross. Although, like other scientists, he must have had tempting offers to stay, there was never any doubt that he wanted to come home. In September he was to have returned to the Royal College of Surgeons to join the new Thrombosis Research Group of the Medical Research Council.

In his work Cross combined enthusiasm with cautiousness in establishing and interpreting his experimental results. He was full of ideas, but his careful chemical training never allowed them to run away with him. $\mathrm{He}$ was independent, but very co-operative.

Cross made friends with all who knew him. He was the essence of kindness and helpfulness. He had the ability to get on well with people whose opinions were very different from his; this was important, because he had strong views on social affairs. Almost always he was cheerful, exuberant really; when something went wrong and he became temporarily less than completely happyone never saw him gloomy -it was still good to be with him because his emotions were so honest, spontaneous, and open.

Cross had a happy and settled family life in a village where he was very much part of the landscape. He played cricket and shove-ha'penny; and quietly he visited the lonely old people to cheer them up. His family, friends and country suffer grievously by his death. Indeed it is almost impossible to believe that this excep. tionally lively, happy, very-present figure will not be returning to us.

\section{NEWS and VIEWS}

\section{Sprengel's Pump}

IT is now almost 100 years since Herman Sprengel developed his mercury air-pump-an invention which he described to the Chemical Society in 1865, and one which proved to have an important influence on the development of both science and industry in the latter part of the nineteenth century, especially in the development of the electric lamp, discharge tubes, the discovery of the socalled 'inert' gases, etc. Sprengel, the man, has gained little notice from biographers, but his mercury pump has been the focus of much attention. Born in Schillerslage, Hanover, on August 29, 1834, Sprengel was educated first at Göttingen and then Heidelberg Universities. Coming to Britain, he worked for three years as an assistant in the chemical laboratory of the University of Oxford, and then as assistant in the laboratories of Guy's and St. Bartholomew's Hospitals. During 1865-70 he was employed in the Farmer's Chemical works and became a naturalized Briton. He devoted much time to detonation and explosives, and was the first to direct attention to the value of picric acid as an explosive when fired by a detonator. For the rest of his life he was engaged on his own inventions and patents, but his chef-d'ouvre was his pump, especially once he became one of the eminent men fascinated by the power of the vacuum. Toricelli, Von Guericke with his famous Magdeburg hemispheres, Boyle, Papin, Geissler and Töpler all joined this 'cult of the vacuum', while Röntgen, Crookes, Dewar, Langmuir and Fleming continued the theme with the aid of Sprengel's pump. Sprengel was elected a Fellow of the Royal Society of London in 1878. Mercury with its stable nature, its inertness towards gases and vapours, certainly proved a boon before the advent of high-vacuum pumps, and made it possible for Sprengel and his followers to show up the short-sightedness of Lear's reply, "Why, no, boy; nothing can be made out of nothing" when the Fool questions, "Can you make no use of nothing, nuncle?".

\section{Social Psychology in the University of Sussex: \\ Prof. Marie Jahoda}

MARIE JAHODA, who is at present Head of the Department of Psychology and Social Science at Brunel College, studied psychology at the University of Vienna, where she received her Ph.D. in 1932. In Vionna sho was assistant director and then director of a research institute. In 1937 she came to England and soon afterwards was awarded the Pinsent-Darwin fellowship at the 